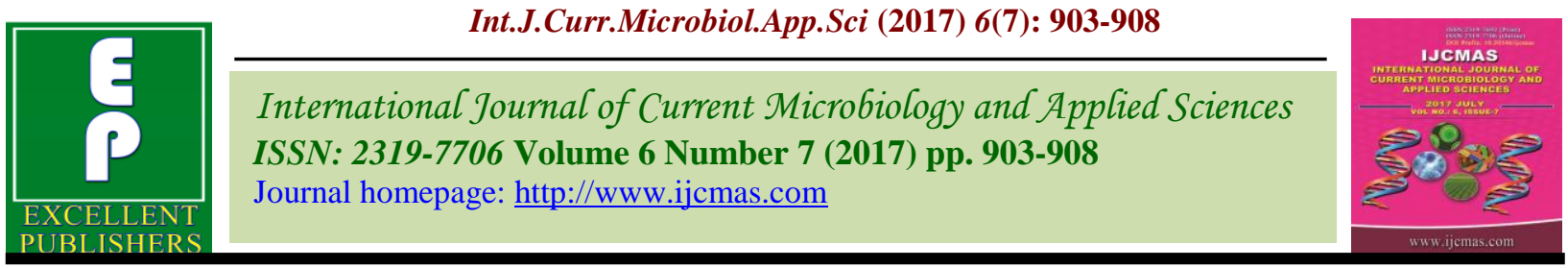

Original Research Article

https://doi.org/10.20546/ijcmas.2017.607.111

\title{
Screening of Tomato Cultivars (Hybrids/Varieties) for Whitefly, B. tabaci in Field Condition
}

\author{
B. Jamuna*, M. Bheemanna, A.C. Hosamani, Timmanna and R. Naveen \\ Department of Agricultural Entomology, College of Agriculture Raichur, \\ University of Agricultural Sciences, Raichur, Karnataka-584102 \\ *Corresponding author
}

\begin{tabular}{|c|c|}
\hline & A B S T R A C T \\
\hline & $\begin{array}{l}\text { The Screening of tomato cultivars (hybrids/ varieties) for whiteflies in field condition was } \\
\text { carried out during 2012-13. All the experimental studies were conducted at Main } \\
\text { Agriculture Research Station Raichur Karnataka. The results revealed that, } 15 \text { Days after }\end{array}$ \\
\hline $\begin{array}{l}\text { Ke y w o r d s } \\
\text { B. tabaci, } \\
\text { Cultivar, } \\
\text { Screening, } \\
\text { L. esculentum. }\end{array}$ & $\begin{array}{l}\text { transplanting Vybhav recorded least number of adult (1.00/ three leaves) followed by Arka } \\
\text { Samrat, PTR } 4 \text { was significantly preferred variety with highest }(4.50) \text { number of adult } \\
\text { whitefly population. } 30 \text { Days after transplanting the variety Vybhav maintained its } \\
\text { superiority over other cultivars (hybrids/varieties) with significantly least (1.25) number of } \\
\text { adult whitefly per three leaves. Adult whitefly preference was more on PTR } 6 \text { and PTR } 4 \\
\text { and least preference was observed in Vybhav, Arka Samrat, Arka Rakshaka and Arka }\end{array}$ \\
\hline Article Info & $\begin{array}{l}\text { Ananya. } 45 \text { Days after transplanting wherein Vybhav recorded least ( } 1.50 / \text { three leaves) } \\
\text { adult whitefly population followed by Arka Samrat and Arka Rakshaka which recorded }\end{array}$ \\
\hline $\begin{array}{l}\text { Accepted: } \\
\text { 14 June } 2017 \\
\text { Available Online: } \\
\text { 10 July } 2017\end{array}$ & $\begin{array}{l}3.25 \text { and } 3.50 \text { adult whitefly per three leaves respectively. PTR } 4 \text {, PTR } 6 \text { and Arka } \\
\text { Ananya, recorded } 6.25,6.00 \text { and } 4.00 \text { adult whitefly per three leaves respectively. } \\
\text { Vybhav variety recorded least per cent ToLCV disease incidence }(7.79 \%) \text { whereas, Arka } \\
\text { Samrat, Arka Rakshaka and Arka Ananya recorded } 14.98,18.57 \text { and } 20.7 \text { per cent disease }\end{array}$ \\
\hline & $\begin{array}{l}\text { incidence respectively and were on par with each other. PTR } 4 \text { and PTR } 6 \text { recorded the } \\
\text { maximum per cent disease incidence of } 27.14 \text { and } 28.58 \text { per cent respectively and were on } \\
\text { par with each other. }\end{array}$ \\
\hline
\end{tabular}

\section{Introduction}

Tomato (Lycopersicon esculentum Mill.) is one of the important and widely grown vegetable crops of both tropics and subtropics of the world, belonging to the family Solanaceae and ranks second in importance among vegetables. Tomato can be grown throughout the year. Globally tomato is cultivated over an area of 45.82 lakh hectares with an annual production of 1505.13 lakh tonnes with a productivity of $32.8 \mathrm{t} /$ ha (Anon., 2011). In India it is cultivated in 9.33 lakh hectares with a production of 193.77 lakh tonnes. In Karnataka, tomato is cultivated on an area of 0.59 hectares with a production of 20.70 lakh tonnes and occupies second position in production (2069.70 ton) after Andhra Pradesh (6195.56 ton), (Anon., 2012). Though, the area under tomato cultivation is high, the productivity (15 t/ ha) is low, this is attributed to the potential loss in yield due to various biotic and abiotic factors. Among biotic factors, Insect pest, like fruit borer, Helicoverpa armigera (Hab.) serpentine leafminer, (Liriomyza trifolii) aphids (Myzus 
persicae or Aphis gossypii), mites (Tetranychus spp.), thrips (Thrips tabaci) armyworm, Spodoptera litura (Fab.), mealybugs (Maconellicoccus sp.), nematodes and diseases like fungal, bacterial, phytoplasma infections and also crop is affected by large number of viral diseases (Anonymous, 2011). Of all these, the whitefly, Bemisia tabaci (Genn.) transmitting many deadly diseases in solanaceous, cucurbitaceous vegetable crops and pulse crops. Tomato Leaf Curl Virus Disease (ToLCVD) having a greater negative impact on production of tomato.

Tomato whitefly, Bemisia tabaci (Gennadius) was described over 100 years ago as a pest of tobacco in Greece. It is a phloem-feeding insect. It rose to international prominence in the mid to late 1970's and since then it has risen to the status as one of the most damaging and globally known pests of open field and protected crops.

Both adults and nymphs of $B$. tabaci suck plant sap from the underside of leaves causing chlorotic spots. Continuous feeding affects the physiology of plant leading to detrimental effect on all stages of the crop. Important role of B.tabaci as a vector of several Gemini viruses such as leaf curl virus of tomato and okra, yellow mosaic virus of beans, tobacco leaf curl virus, etc. Tomato leaf curl virus (ToLCV) is a geminivirus (Geminiviridae: subgroup - III) which is the most important and destructive viral pathogen in many parts of India. The incidence of ToLCV in tomato growing areas of Karnataka ranged from 17 to 100 per cent in different seasons and 50 to 70 per cent yield loss was observed in tomato $\mathrm{Cv}$. Pusa Ruby grown in February to May whereas yield loss was above 90 per cent, when infection occurred within four weeks after transplanting in the field (Vasudeva and Samraj, 1948; Sastry and Singh, 1973; Saikia and Muniyappa, 1989).

\section{Materials and Methods}

Six tomato cultivars (hybrids/ varieties) viz., Vybhav (UAS Bengaluru), Arka Ananya, Arka Rakshak and Arka Samrat (IIHR), PTR 6 and PTR 4 from UAS Raichur collected. These collected cultivars were sown separately in raised nursery bed and protected by using nylon net (40 mesh). Recommended agronomic practices were followed (watering, weeding, and fertilizer application) to raise healthy seedlings. Twenty five days after sowing the seedlings were transplanted to main field with spacing of $90 \times 60 \mathrm{~cm}$. For each cultivar a plot size of $1.8 \mathrm{~m} \mathrm{X} 4.2 \mathrm{~m}$ was maintained and in each cultivar 21 plants with four replications comprised and no pesticides were applied to these plots.

In each cultivar randomly three plants were selected and tagged to examine adult whitefly population at 15,30 and 45 days after transplanting (DAT), and finally tomato leaf curl virus disease incidence was also recorded in each cultivar (hybrids/ varieties) to know the susceptibility of cultivar to disease.

\section{Results and Discussion}

15 Days after transplanting there was significant difference in the adult whitefly, $B$. tabaci population on different cultivars (hybrids/ varieties). Vybhav recorded least number of adult (1.00/ three leaves) followed by Arka Samrat, Arka Rakshaka, Arka Ananya and PTR 6 which recorded 2.50, 2.63, 2.73 and 4.25 adult whiteflies respectively and were on par with each other. PTR 4 was significantly preferred variety with highest (4.50) number of adult whitefly population.

30 Days after transplanting the variety Vybhav maintained its superiority over other cultivars (hybrids/ varieties) with significantly least (1.25) number of adult whitefly per three leaves. Arka Samrat, Arka Rakshaka and Arka 
Ananya cultivars recorded 3.00, 3.25 and 3.63 adult $B$. tabaci per three leaves respectively and were on par with each other. Both PTR 6 and PTR 4 recorded 5.25 and 4.88 adult whitefly per thee leaves respectively. Adult whitefly preference was more on PTR 6 and PTR 4 and least preference was observed in Vybhav, Arka Samrat, Arka Rakshaka and Arka Ananya (Table 1).

Table.1 Screening of tomato cultivars (hybrids/ varieties) for whitefly, Bemisia tabaci in field condition

\begin{tabular}{|c|c|c|c|c|}
\hline \multirow[t]{2}{*}{ Sl. No. } & \multirow[t]{2}{*}{ Tomato cultivar } & \multicolumn{3}{|c|}{ Whitefly population per three leaves* } \\
\hline & & 15DAT & 30DAT & 45DAT \\
\hline 1. & PTR6 & $\begin{array}{l}4.25{ }^{c} \\
(2.90)^{c}\end{array}$ & $\begin{array}{l}5.25{ }^{c} \\
(3.18)^{c}\end{array}$ & $\begin{array}{r}6.00 \\
(2.54)^{\mathrm{c}}\end{array}$ \\
\hline 2. & PTR4 & $\begin{array}{l}4.50{ }^{\mathrm{c}} \\
(2.98)^{\mathrm{c}}\end{array}$ & $\begin{array}{l}4.88{ }^{c} \\
(3.08)^{c}\end{array}$ & $\begin{array}{l}6.25{ }^{c} \\
(2.59)^{c}\end{array}$ \\
\hline 3. & ARKA ANANYA & $\begin{array}{l}2.75 \\
(2.40)\end{array}$ & $\begin{array}{l}3.63 \\
(2.70)\end{array}$ & $\begin{array}{l}4.00{ }^{\mathrm{b}} \\
(2.12)\end{array}$ \\
\hline 4. & ARKA RAKSHAKA & $\begin{array}{l}2.63 \\
(2.34)^{b}\end{array}$ & $\begin{array}{l}3.25 \\
(2.58)\end{array}$ & $\begin{array}{l}3.50 \\
(2.00)\end{array}$ \\
\hline 5. & ARKA SAMRAT & $\begin{array}{l}2.50{ }^{\mathrm{b}} \\
(2.30)^{2}\end{array}$ & $\begin{array}{l}3.00{ }^{\mathrm{b}} \\
(2.49)\end{array}$ & $\begin{array}{l}3.25 \\
(1.93)^{b}\end{array}$ \\
\hline 6. & VYBHAV & $\begin{array}{l}1.00 \\
(1.63)^{a}\end{array}$ & $\begin{array}{l}1.25 \\
(1.75)^{a}\end{array}$ & $\begin{array}{l}1.50{ }^{\mathrm{a}} \\
(1.40)^{2}\end{array}$ \\
\hline \multicolumn{2}{|c|}{ SEm \pm} & 0.07 & 0.10 & 0.09 \\
\hline \multicolumn{2}{|c|}{$\mathrm{CD}(0.05)$} & 0.22 & 0.29 & 0.28 \\
\hline
\end{tabular}

DAT-Days after transplanting, Figures in the parenthesis are $\sqrt{x}+0.5$ transformed values; Mean followed by same letter in the column do not differ significantly by DMRT $(\mathrm{P}=0.05)$, *Means of four replications.

Table.2 Tomato leaf curl disease incidence in different cultivars in field condition

\begin{tabular}{|l|l|l|}
\hline Sl. No. & Tomato cultivar & $\begin{array}{l}\text { Disease incidence* } \\
(\mathbf{\%})\end{array}$ \\
\hline 1. & PTR6 & $\begin{array}{l}28.58 \\
(32.27)^{\mathrm{d}}\end{array}$ \\
\hline 2. & PTR4 & $\begin{array}{l}27.14 \\
(31.35)^{\mathrm{d}}\end{array}$ \\
\hline 3. & ARKA ANANYA & $\begin{array}{l}20.71 \\
(26.97)^{\mathrm{c}}\end{array}$ \\
\hline 4. & ARKA RAKSHAKA & $\begin{array}{l}18.57 \\
(25.44)^{\mathrm{bc}}\end{array}$ \\
\hline 5. & ARKA SAMRAT & $\begin{array}{l}14.98 \\
(22.70)^{\mathrm{b}}\end{array}$ \\
\hline 6. & VYBHAV & $\begin{array}{l}7.79 \\
(16.01)^{\mathrm{a}}\end{array}$ \\
\hline SEm \pm & & $\mathbf{1 . 3 0}$ \\
\hline CD $(\mathbf{0 . 0 5})$ & & $\mathbf{3 . 9 6}$ \\
\hline
\end{tabular}

Figures in the parenthesis are arcsine transformed values, Means followed by same letter do not differ significantly by $\operatorname{DMRT}(\mathrm{P}=0.05) *$ Means of four 
Fig.1 Screening of tomato cultivars for B. tabaci in field condition

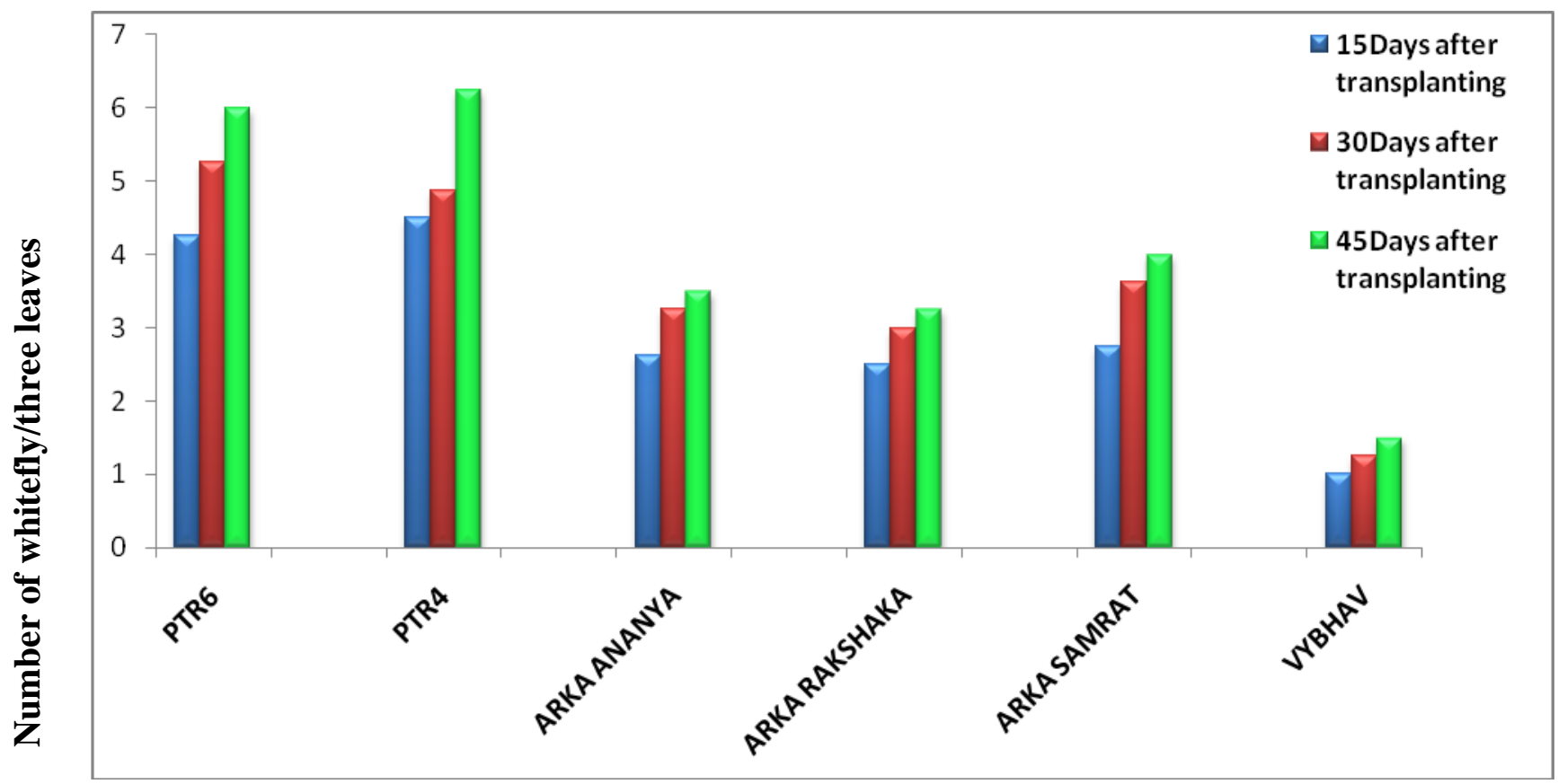

\section{Different tomato cultivars}

Fig.2 ToLCV disease incidence of tomato cultivars in response to whitefly, B. tabaci in field condition

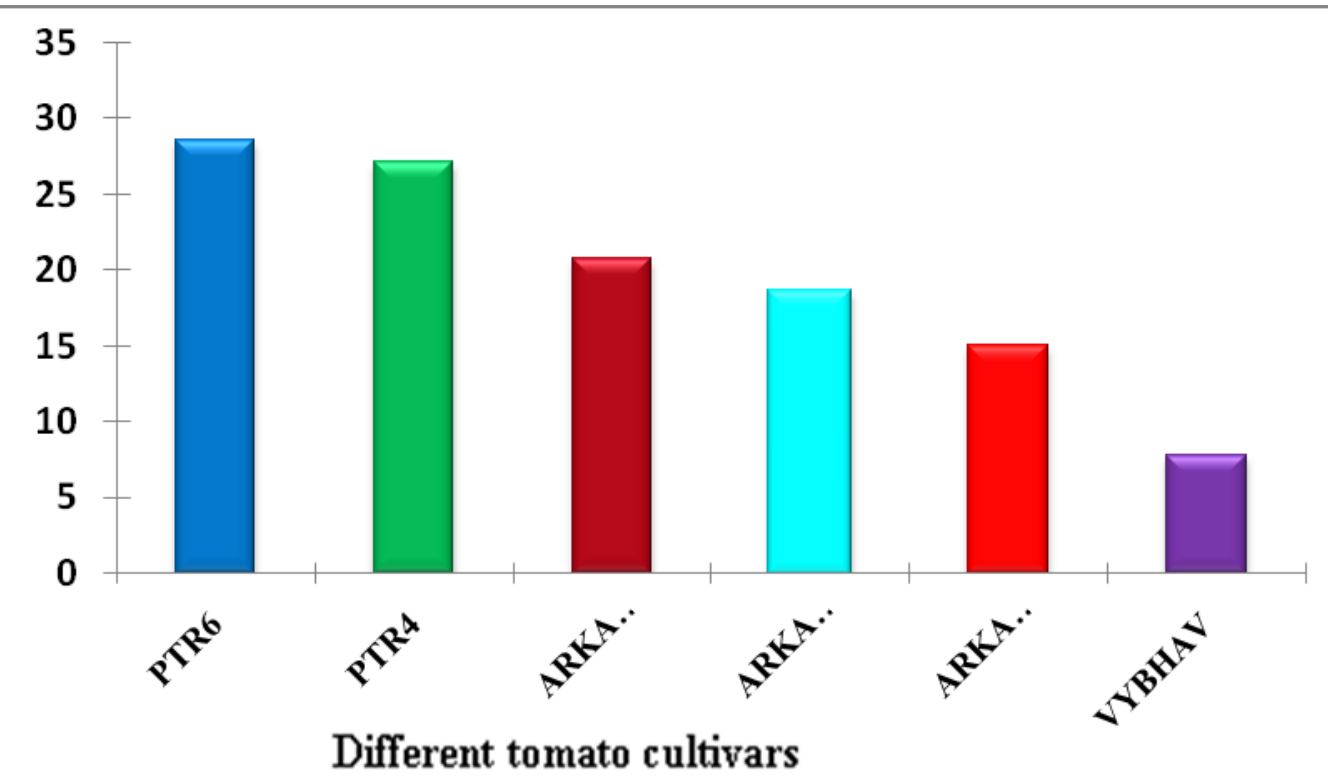


Plate.1 Highly preferred tomato cultivar PTR-6

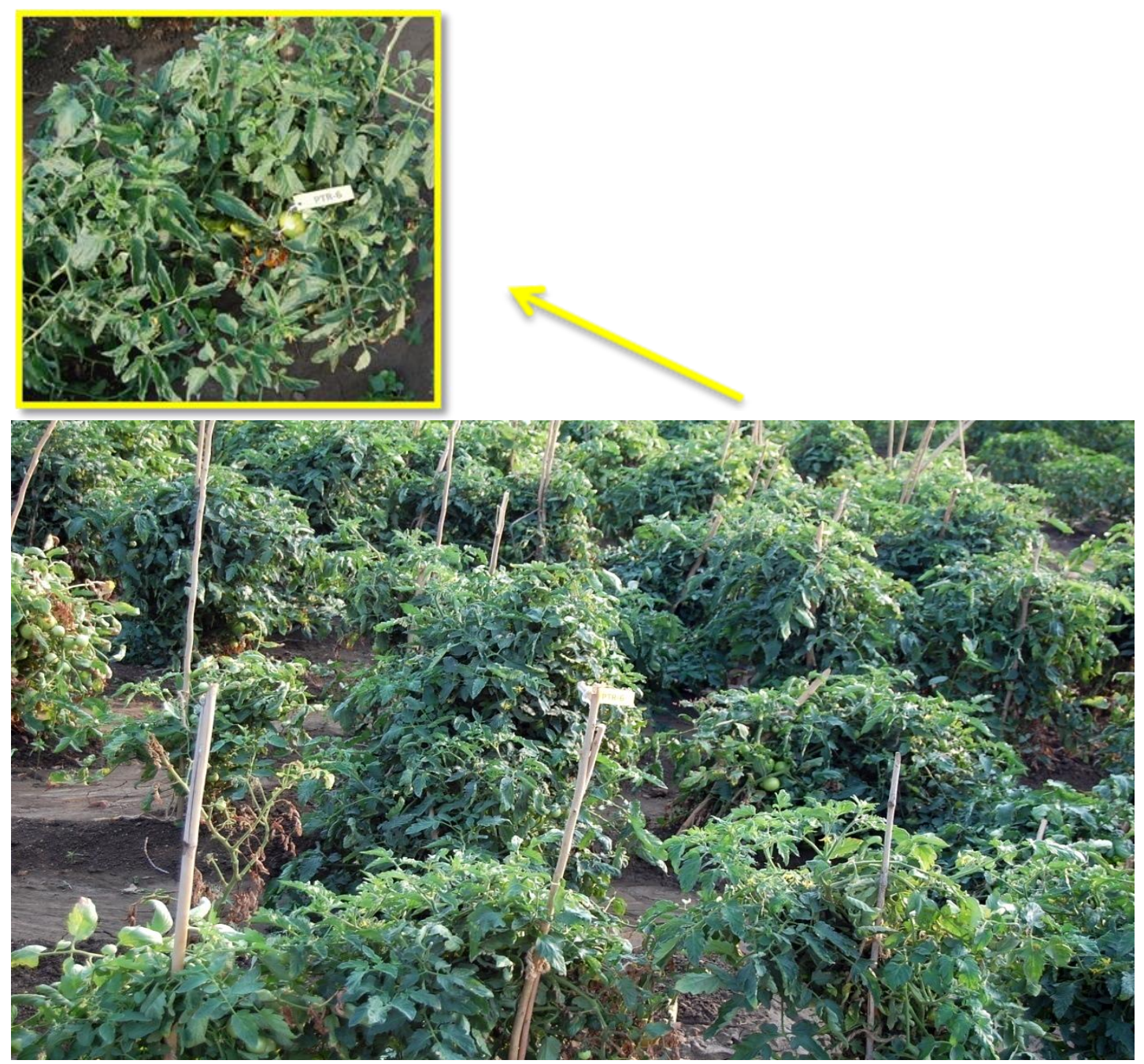

Similar trend was observed at 45 days after transplanting wherein Vybhav recorded least (1.50/ three leaves) adult whitefly population followed by Arka Samrat and Arka Rakshaka which recorded 3.25 and 3.50 adult whitefly per three leaves respectively. PTR 4, PTR 6 and Arka Ananya, recorded 6.25, 6.00 and 4.00 adult whitefly per three leaves respectively (Fig. 1).

Tomato leaf curl disease incidence in different cultivars in response to $B$. tabaci in field condition

The data on per cent ToLCV disease incidence and yield in response to whitefly, B. tabaci in different cultivars under field condition is presented here Vybhav variety recorded least per cent ToLCV disease incidence (7.79\%) whereas, Arka Samrat, Arka Rakshaka and Arka Ananya recorded 14.98, 18.57 and 20.7 per cent disease incidence respectively and were on par with each other. PTR 4 and PTR 6 recorded the maximum per cent disease incidence of 27.14 and 28.58 per cent respectively and were on par with each other (Table 2).

Among six cultivars (hybrids/varieties) PTR 6 and PTR 4 recorded significantly highest (28.58 and $27.14 \%)$ disease incidence. Hybrids Arka Samrat, Arka Rakshaka and 
Arka Ananya recorded least (14.98, 18.57 and $20.71 \%$ ) disease incidence compared to PTR series (Fig. 2). Variety Vybhav recorded significantly lowest $(7.79 \%)$ disease incidence and categorised as highly tolerant to ToLCV disease which is transmitted by vector whitefly (Plate 1).

These observations are in conformity with Ramazeame (2012) who reported Vybhav and Nandi were highly resistant cultivars and Arka Vikas was the most susceptible Variety. There was no literature available on remaining cultivars (hybrids/ varieties) to discuss.

\section{References}

Anonymous. 2011. (http://www.tomatoleafcurlandwhitefly.o $\mathrm{rg} /$ release.html).

Anonymous. 2012. Indian Horticulture Database, National Horticultural Board, Ministry of Agriculture, Government of India.

Ramazeame, L. 2012. Integrated Management of Whitefly, Bemisia tabaci (Gennadius) on Tomato. Ph. D. thesis, University of Agricultural Science, Bangalore, pp 74.

Saikia, A.K. and Muniyappa, V. 1989. Epidemiology and control of tomato leaf curl virus in Southern India. Trop. Agri., 66: 350-354.

Sastry, K.S.M. and Singh, S.J. 1973. Assessment of losses of tomato caused by tomato leaf curl virus. Indian $J$. Mycol., Plant Pathol., 3: 50- 54.

Vasudeva, R.S. and Samraj. 1948. Leaf curl disease of tomato. Phytopathol., 18: 364369.

\section{How to cite this article:}

Jamuna, B., M. Bheemanna, A.C. Hosamani, Timmanna and Naveen, R. 2017. Screening of Tomato Cultivars (Hybrids/Varieties) for Whitefly, B. tabaci in Field Condition. Int.J.Curr.Microbiol.App.Sci. 6(7): 903-908. doi: https://doi.org/10.20546/ijcmas.2017.607.111 